\title{
Effectors of plant parasitic nematodes that re-program root cell development
}

\author{
Samira Hassan ${ }^{\mathrm{A}, \mathrm{B}}$, Carolyn A. Behm ${ }^{\mathrm{A}}$ and Ulrike Mathesius ${ }^{\mathrm{B}, \mathrm{C}}$ \\ A Division of Biomedical Science and Biochemistry, Research School of Biology, Building 41A, \\ Australian National University, Canberra, ACT 0200, Australia. \\ ${ }^{B}$ Division of Plant Science and ARC Centre of Excellence for Integrative Legume Research, \\ Research School of Biology, Building 41A, Australian National University, Canberra, ACT 0200, Australia. \\ ${ }^{\mathrm{C}}$ Corresponding author. Email: ulrike.mathesius@anu.edu.au
}

\begin{abstract}
Plant parasitic nematodes infect the roots of a wide range of host plants. Migratory endo- or ectoparasites feed off the roots temporarily, but sedentary endoparasites are biotrophic parasites that invade roots and establish a permanent feeding site by re-directing root cell development. Feeding sites develop after injection of nematode effectors into plant cells through a stylet. In this review, we concentrate on several recently-identified effectors and discuss their possible functions in redirecting root cell development. We give examples of effectors that regulate host gene expression, interact with specific host proteins or mimic plant signalling molecules.
\end{abstract}

Additional keywords: auxin, cell cycle, CLE peptide, cyst, cyst nematode, nematode, root-gall, root-knot.

\section{Nematode effectors and root cell development}

Nematode effectors are a collective of protein and other molecules secreted by the nematode to affect the host defence response, facilitate penetration of the host tissue and establish a feeding site (Vanholme et al. 2004; Davis et al. 2008; Bird and Opperman 2009; Hogenhout et al. 2009).

Plant parasitic nematodes can be divided into four major feeding groups: sedentary endo- or ectoparasites and migratory endo- or ectoparasites (Decraemer and Hunt 2006). Although their behaviours are very different, all four groups possess a stylet to puncture the host cells from which they feed. The stylet is also used to inject effector molecules into the host apoplast (Wang et al. 1999; Goellner et al. 2001; Jaubert et al. 2005) and into the cytoplasm (Wang et al. 2010).

In order to penetrate the host and to migrate through the host tissues, the nematodes secrete - principally from the subventral or dorsal esophageal glands - a variety of proteins that soften and break down the cell walls of the host. These comprise a range of enzymes that digest cellulose, pectin and other components of the cell walls, along with binding or 'chaperone' proteins (e.g. cellulose binding proteins and expansin-like proteins) that are secreted simultaneously with the enzymes (Table 1). The latter are hypothesised to enable, or accelerate, the cell wall digestion process and, hence, improve both the speed of parasite movement through host tissues and the penetration of the stylet into the host cells, thus, increasing their feeding efficiency.

After penetration, the sedentary nematodes such as the rootknot (RKN) (Meloidogyne spp.) and cyst nematodes (CNs) (Globodera and Heterodera spp.) develop specialised feeding cells within the roots and draw nutrients away from the host
(Caillaud et al. 2008). In both cases, multinucleate feeding cells are established: in RKN infections this occurs by stimulation of karyokinesis without cytokinesis, leading to giant cell (GC) formation; in $\mathrm{CN}$ infections by endoreduplication and fusion of many hundred cells to form syncytia (Jones 1981; Goverse et al. 2000). Extensive cell division and enlargement of surrounding cells leads to the formation of large galls by RKNs on the roots, whereas no gall is formed in $\mathrm{CN}$-infected roots (Fig. 1). In order to induce these extensive cellular modifications, the parasites secrete a barrage of effector molecules aimed at reprogramming cells to form nematode feeding sites (NFS) and redirecting the root cell development.

Nematode effectors have been identified through various approaches (summarised by Davis et al. 2009), including bioinformatics (Roze et al. 2008; Elling et al. 2009), by expression profiling of genes expressed in the (esophageal glands of) nematodes that produce effectors (Qin et al. 2000; Gao et al. 2003; Tytgat et al. 2004; Ithal et al. 2007; Davis et al. 2008; Elling et al. 2009) and through direct proteomic identification of secreted proteins (Jaubert et al. 2002b; Bellafiore et al. 2008). Microaspiration of esophageal gland contents of Heterodera glycines and Meloidogyne incognita to isolate mRNA for differential expression studies has been particularly successful in the identification of effectors (Gao et al. 2001a, 2003; Wang et al. 2001; Huang et al. 2003, 2004). A summary of the effector molecules currently known from the major nematode parasites is provided in Table 1. The wide host range of many nematodes suggests that their effectors target essential mechanisms for root cell development. This review focusses on recent progress in effector biology of plant 
Table 1. Selected nematode effectors and their potential functions

\begin{tabular}{|c|c|c|c|}
\hline Effector name & Species & Putative function & References \\
\hline \multicolumn{4}{|c|}{ Facilitation of migration } \\
\hline$\beta$-1,4-endoglucanase & $\begin{array}{l}\text { Meloidogyne incognita, } \\
\text { Globodera rostochiensis, } \\
\text { G. tabacum, Heterodera } \\
\text { glycines, Pratylenchus } \\
\text { penetrans }\end{array}$ & $\begin{array}{l}\text { Cell-wall degradation: hydrolyses } 1,4- \\
\beta \text {-D-glucosidic linkages in 1,4- } \beta \text {-D-glucans } \\
\text { such as cellulose, lichenin and cereal } \beta \text {-D- } \\
\text { glucans. Knocking down of the expression } \\
\text { of cellulase by soaking in dsRNA led to a } \\
\text { reduction in penetration of the plant by the } \\
\text { nematodes }\end{array}$ & $\begin{array}{l}\text { Smant et al. (1998), de Boer et al. } \\
\text { (1999), Lilley et al. (1999), Rosso } \\
\text { et al. (1999), Wang et al. (1999), } \\
\text { Goellner et al. (2000), Uehara et al. } \\
\text { (2001), Gao etal. (2004), Chen et al. } \\
\text { (2005), Ledger et al. (2006), Ithal } \\
\text { et al. (2007), Roze et al. (2008), } \\
\text { Haegeman et al. (2009b), Rehman } \\
\text { et al. (2009a) }\end{array}$ \\
\hline
\end{tabular}

及-1,3-endoglucanase Bursaphelenchus xylophilus, B. mucronatus

Arabinogalactan endo1,4 - $\beta$-galactosidase Pectate lyase

Endoxylanase

Polygalacturonase

Cellulose binding protein

Expansin and
expansin-like

GSB24

Venom allergen like protein (vap-1, vap-2)

Zinc finger protein, $10 \mathrm{~A} 06$

Secreted SPRY domain-containing proteins (SPRYSEC)
H. schachtii

G. rostochiensis, B. xylophilus, H. glycines, M. incognita, M. javanica, M. chitwoodi

M. incognita, Radopholus similis

M. incognita

H. glycines, H. schachtii, M. incognita, M. javanica, M. arenaria, G. pallida

G. rostochiensis, B. xylophilus, B. mucronatus, Ditylenchus africanus

H. glycines

H. glycines, M. incognita, H. schachtii, B. xylophilus, D. africanus, G. pallida

H. glycines, H. schachtii

G. pallida, G. rostochiensis
$1,3-\beta$-D-glucosidic linkages in

$1,4-\beta$-D-glucans such as laminarin and fungal 1,3- $\beta$-D-glucans

Cell-wall degradation: hydrolyses $1,4-\beta$ galactosidic linkages in arabinogalactans

Cell wall degradation: cleaves internal $\alpha-1,4$ linkages of pectate (polygalacturonate)

Cell wall degradation: hydrolyses $1,4-\beta$ xylosidic linkages in xylans

Cell wall degradation: hydrolyses $1,4-\alpha-\mathrm{D}-$ galactosiduronic linkages in pectate and other galacturonans

Facilitates cell wall degradation. In planta silencing of cellulose binding protein 3B05 may slow down parasitism of host plant; however reproducible data are currently lacking

Cell wall extension/softening by loosening non-covalent bonds

Putative secreted proline-rich glycoprotein; function unknown

\section{Defence}

Exact function unknown. Similarity to proteins from animal-nematode parasites and insects. Possibly involved in transition to parasitic stage

Interacts with spermidine synthase 2 , suggested to provide a protective antioxidant environment in the syncytium and inhibit defence responses. Silencing of $10 \mathrm{~A} 06$ by plant-mediated RNAi resulted in up to $42 \%$ reduction of developing females

SPRYSEC proteins are suggested to regulate host defence responses. Two members were shown to interact with typical plant resistance proteins of the NB-LRR family. Functions of other SPRYSEC proteins are unknown, some show similarity to ran binding protein to microtubules (RanBPM), a protein that may interact with microtubules
Vanholme et al. (2006, 2009)

Popeijus et al. (2000), de Boer et al. (2002), Doyle and Lambert (2002), Kikuchi et al. (2004, 2006), Huang et al. (2005), Ithal et al. (2007), Bellafiore et al. (2008), Roze et al. (2008)

Mitreva-Dautova et al. (2006), Bellafiore et al. (2008), Haegeman et al. (2009b)

Jaubert et al. (2002a), Bellafiore et al. (2008)

Ding et al. (1998), Huang et al. (2003), Gao et al. (2004), Ithal et al. (2007), Adam et al. (2008), Bellafiore et al. (2008), Hewezi et al. (2008), Jones et al. (2009)

Ding et al. (1998), Qin et al. (2004), Kudla et al. (2005), Haegeman et al. (2009a), Kikuchi et al. (2009)

Gao et al. (2001a)

Ding et al. (2000), Gao et al. (2001b), Vanholme et al. (2006), Ithal et al. (2007), Wang et al. (2007), Haegeman et al. (2009a), Jones et al. (2009), Kang et al. (2009)

Sindhu et al. (2009), Hewezi et al. (2010)

Qin et al. (2000), Blanchard et al. (2005), Jones et al. (2009), Rehman et al. (2009b), Sacco et al. (2009) 
Table 1. (continued)

\begin{tabular}{ll}
\hline Effector name & Species \\
\hline $\begin{array}{l}\text { FAR-1 (fatty acid and } \\
\text { retinol binding } \\
\text { protein) }\end{array}$ & G. pallida \\
Calreticulin & M. incognita, H. glycines \\
$\begin{array}{l}\text { Annexin-like proteins } \\
\text { (HgF401/HsF401) }\end{array}$ & H. glycines, H. schachtii
\end{tabular}

\author{
Calcium dependent \\ protein kinase \\ (CDPK) \\ Translationally- \\ controlled tumour \\ proteins (TCTP)
}

Auxin and cytokinin

Mitogenic peptides

Chorismate mutase

Peptide 16D10

\footnotetext{
Ubiquitin-like proteins (UBI, RING-H2, SKP-1)
}

Putative function References \\ Surface protein that can bind linoleic and \\ Prior et al. (2001) \\ linolenic acid and can inhibit their \\ modification by lipoxygenases. Thus, it may \\ interfere with defence responses by \\ modulating jasmonic acid signalling \\ pathway in hosts \\ Calcium signalling \\ Calcium binding protein. Multiple putative \\ roles in cell cycle, NFS initiation and \\ maintenance. No direct evidence of \\ involvement in feeding site establishment \\ Involved in calcium-regulated activities \\ associated with membrane surfaces. \\ Jaubert et al. (2002b, 2005), Ithal et al. \\ (2007) \\ Ithal et al. (2007), Davis et al. (2009), \\ Patel et al. (2010)
}

Potentially function to regulate ion transport

across cell membrane and to act against

reactive oxygen species (ROS). HsF401

interacts with an Arabidopsis

oxidoreductase and overexpression in

Arabidopsis confers hypersusceptibility to

H. schachtii

M. incognita

Root hair formation and root cell elongation. Specific role in feeding site development unknown

M. incognita Cell growth, progression of cell cycle, malignant transformation, protection against apoptosis and stress. Specific role in feeding site development unclear

NFS initiation, development and maintenance

H. schachtii, M. incognita

G. rostochiensis

M. javanica, H. glycines, G. pallida

M. incognita

H. glycines, H. schachtii
Regulation of cell division and differentiation in plants. Whether nematode-derived auxin and cytokinin are required for feeding site development remains unclear

Low molecular weight $(<3 \mathrm{kDa})$ peptides were able to stimulate tobacco protoplast division in the presence of synthetic auxin and cytokinin. These peptides might function in the re-activation of the cell cycle during feeding cell formation by a so far unknown mechanism

Suggested to promote pathogenicity and reprogram parenchymal cells into future feeding cells by altering endogenous levels of chorismate-derived compounds such as auxins and flavonoids

Interacts with plant SCARECROW-like (SCL) transcription factors probably to stimulate giant cell initiation. Plantmediated RNAi silencing of 16D10 resulted in smaller and fewer galls

Evidence suggests manipulation of ubiquitin pathways alters plant metabolism. RING$\mathrm{H} 2$ and S-phase kinase associated protein (SKP-1) are part of a complex involved in transferring UBI markers to target proteins and allow cell cycle progression. In planta RNAi silencing of ubiquitin-like genes 4G06 and SKP-1 like genes 8H07 in cyst nematodes led to a reduction in parasitism of the host by up to $64 \%$
Bellafiore et al. (2008)

Bellafiore et al. (2008)

de Meutter et al. (2003, 2005)

Goverse et al. (1999)

Bekal et al. (2003), Doyle and Lambert (2003), Gao et al. (2003), Ithal et al. (2007), Jones et al. (2009)

Huang et al. (2006a, 2006b)

Estelle (2001), Gao et al. (2003), Tytgat et al. (2004), Sindhu et al. (2009) 
Table 1. (continued)

\begin{tabular}{|c|c|c|c|}
\hline Effector name & Species & Putative function & References \\
\hline $\begin{array}{l}\text { Ubiquitin extension } \\
\text { proteins }\end{array}$ & $\begin{array}{l}\text { H. schachtii, G. pallida, } \\
\text { H. glycines }\end{array}$ & $\begin{array}{l}\text { Putative regulatory role in syncytium } \\
\text { formation but no direct evidence so far. } \\
\text { Protein may be targeted to host nucleolus }\end{array}$ & Tytgat et al. (2004), Jones et al. (2009) \\
\hline $14-3-3$ protein & M. incognita & $\begin{array}{l}\text { 14-3-3 proteins have an array of roles as they } \\
\text { interact with other proteins - chaperones to } \\
\text { prevent proteolysis of proteins, adaptors for } \\
\text { mediating protein-protein interaction, } \\
\text { regulators of intracellular protein } \\
\text { distribution, transcriptional regulators. } \\
\text { During a plant-nematode interaction these } \\
\text { proteins may have a role in co-ordination of } \\
\text { mitosis, metabolism, stress response and } \\
\text { organelle trafficking. Mechanisms of action } \\
\text { are unknown }\end{array}$ & $\begin{array}{l}\text { Jaubert et al. (2004), Ithal et al. (2007) } \\
\text { Davis et al. (2009) }\end{array}$ \\
\hline $\begin{array}{l}\text { Histones, helicases, } \\
\text { RNA and DNA } \\
\text { binding proteins, } \\
\text { Nucleosome } \\
\text { Assembly protein }\end{array}$ & M. incognita & $\begin{array}{l}\text { May be involved in transcriptional regulation } \\
\text { during gall formation }\end{array}$ & Bellafiore et al. (2008) \\
\hline $\begin{array}{l}\text { CDC48-like protein } \\
\text { (VCP/CDC48) }\end{array}$ & M. incognita & $\begin{array}{l}\text { Suggested role in stimulating cell proliferation } \\
\text { during gall formation but no direct evidence } \\
\text { for this in plant hosts }\end{array}$ & Bellafiore et al. (2008) \\
\hline $\begin{array}{l}\text { CLAVATA-3 (CLV- } \\
\text { 3)-like peptides }\end{array}$ & G. rostochiensis, H. glycines & $\begin{array}{l}\text { Plant CLE peptides have roles in maintaining } \\
\text { the balance between cell proliferation and } \\
\text { cell differentiation. Nematode CLE } \\
\text { peptides appear to mimic plant CLE } \\
\text { peptides and are suggested to regulate cell } \\
\text { division and differentiation in feeding sites }\end{array}$ & $\begin{array}{l}\text { Wang et al. }(2001,2005,2010), \mathrm{Lu} \\
\text { et al. (2009) }\end{array}$ \\
\hline Cyclophilins & M. incognita & $\begin{array}{l}\text { Other functions } \\
\text { Likely involved in activation of nematode } \\
\text { effectors. Cyclophilins have chaperone } \\
\text { activity - may be involved in protein } \\
\text { trafficking, folding or chromatin } \\
\text { remodelling }\end{array}$ & Bellafiore et al. (2008) \\
\hline $\begin{array}{l}\text { Protein disulfide } \\
\quad \text { isomerases (PDIs) }\end{array}$ & M. incognita & $\begin{array}{l}\text { Possible chaperone functions: overexpression } \\
\text { of PDIs increases total yield of proteins. } \\
\text { PDIs are involved in polymerisation of actin } \\
\text { filaments, gene expression, interactions } \\
\text { between cells, and receptor function } \\
\text { regulation. Direct role in feeding site } \\
\text { formation unknown }\end{array}$ & $\begin{array}{l}\text { Geldhof et al. (2003), Bellafiore et al. } \\
\text { (2008) }\end{array}$ \\
\hline Acid phosphatase & M. incognita & $\begin{array}{l}\text { Secreted from the sub-ventral oesophageal } \\
\text { glands of J2s; may have a digestive role } \\
\text { within the NFS. }\end{array}$ & Huang et al. (2003) \\
\hline Cathepsin proteins & M. incognita, G. pallida & $\begin{array}{l}\text { Cathepsins are cysteine proteases with a } \\
\text { potential digestive role in plant parasitic } \\
\text { nematodes. Plant-mediated RNAi silencing } \\
\text { of cathepsin genes resulted in up to } 60 \% \\
\text { reduction of the nematode population }\end{array}$ & $\begin{array}{l}\text { Shingles et al. (2007), Jones et al. } \\
\text { (2009) }\end{array}$ \\
\hline $\begin{array}{l}\text { Transthyretin-like } \\
\text { protein }(T L P)\end{array}$ & $\begin{array}{l}\text { M. incognita, G. pallida, } \\
\text { Brugia malayi, } \text { R. similis }\end{array}$ & $\begin{array}{l}\text { Putative regulation of plant growth via } \\
\text { interaction with a brassinosteroid receptor } \\
\text { kinase }\end{array}$ & $\begin{array}{l}\text { Bellafiore et al. (2008), Jones et al. } \\
\text { (2009) }\end{array}$ \\
\hline
\end{tabular}

nematode parasites and their role in altering plant cell cycle and root re-development. Many of these effectors are, or may prove to be, essential for successful parasitism and thus are of interest as potential candidates for new control strategies for nematode infections.

\section{Alteration of plant hormone signalling}

The plant hormones auxin and cytokinin are important regulators of cell division and differentiation. Both auxins (de Meutter et al. 2005) and cytokinins (de Meutter et al. 2003) have been detected in plant parasitic nematode secretions, however, it has not been 
(a)

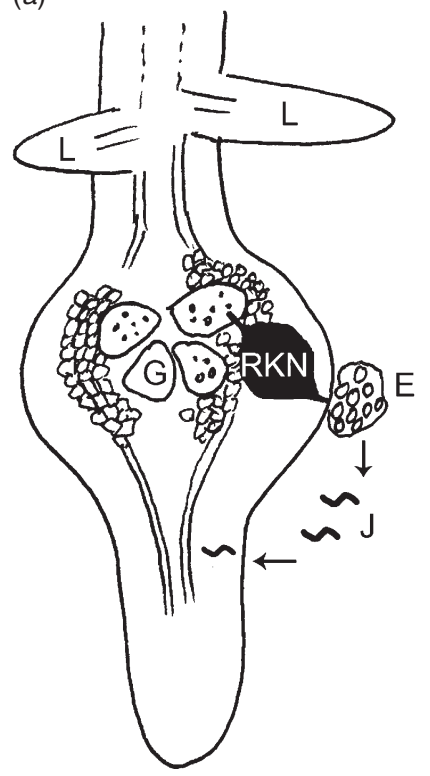

(b)

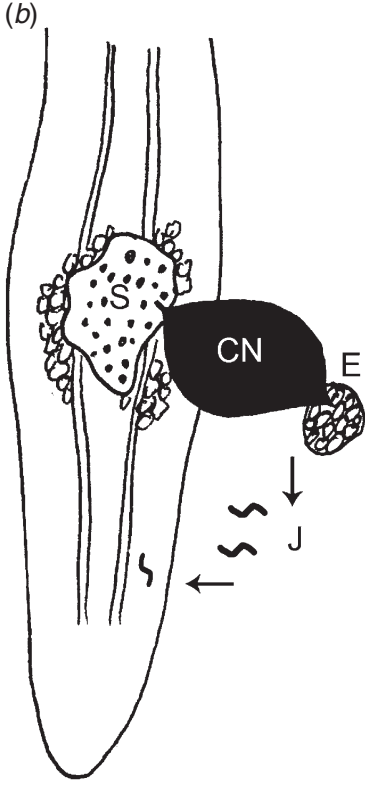

Fig. 1. Alteration of root cell development by parasitic endoparasites. Rootknot and cyst nematodes induce feeding structures in roots by secreting effectors into target cells. (a) Root infected by a root-knot nematode (RKN) forms giant cells $(\mathrm{G})$ in the vascular tissue, surrounded by large numbers of dividing pericycle and cortical cells, leading to the formation of a root-gall. Often lateral roots (L) are initiated near the base of a gall. (b) Roots infected by a cyst nematode $(\mathrm{CN})$ develops a syncytium $(\mathrm{S})$ from vascular tissue due to the dissolution of cell walls of many hundred cells. Eggs (E) are retained within the uterus of the female and some are deposited by the infecting female on the root surface, from which juveniles $(J)$ hatch and later re-infect and penetrate new roots.

established whether these hormones are synthesised de novo and actively secreted by the nematodes. In addition, directly or indirectly, parasitic nematodes alter the expression of auxin response genes (Hutangura et al. 1999; Goverse et al. 2000; Gheysen and Fenoll 2002; Karczmarek et al. 2004) and intricately re-direct the flow of auxin by targeting auxin transport proteins of the PIN gene family (Grunewald et al. 2009a, 2009b), although how this is achieved is not yet known. An enzyme in the shikimate pathway, chorismate mutase $(\mathrm{CM})$, has been identified from $\mathrm{CNs}$ (Bekal et al. 2003; Gao et al.2003) and in the RKN secretome and is likely to have been acquired from bacteria (Doyle and Lambert 2003). The end product of the pathway is chorismate, which forms a precursor to a variety of end products including auxin. Although CMs may be involved in reprogramming of pre-feeding cells, their localisation in the cytoplasm is thought to suppress the induction of defence-related compounds such as flavonoids and salicylic acid (SA).

\section{Peptide effectors}

Goverse et al. (1999) demonstrated the presence of small mitogenic peptides secreted from cyst nematodes that may be responsible for providing the initial activation of the cell cycle. More recently, peptides of the CLE (CLAVATA3/ ENDOSPERM SURROUNDING REGION) family were identified from various cyst nematodes (Wang et al. 2001, 2005, 2010; Lu et al. 2009). The peptide-encoding genes could have originated from plants, as CLE peptide genes have been found only in genomes of plants (Cock and McCormick 2001; Oelkers et al. 2008), where they regulate cell differentiation in shoot and root meristems (Fiers et al. 2007). Alternatively, CLE genes may have evolved independently in nematodes by convergent evolution. The nematode CLE peptides were shown to be functional in plants and are likely to mimic plant CLE peptide signalling pathways (Olsen and Skriver 2003; Wang et al. 2005; Mitchum etal.2008; Lu et al. 2009). Their receptors in the plant are unknown. A peptide with sequence similarity to CLE peptides is $16 \mathrm{D} 10$, a 13 amino acid secreted peptide that is likely to interact with SCARECROW-like transcription factors in the plant during giant cell formation (Huang et al. 2006b).

\section{Protein effectors that interact with plant proteins and signalling pathways}

Several 14-3-3 proteins have been isolated from root-knot nematodes (Jaubert et al. 2004). 14-3-3 proteins can bind to and affect a wide variety of plant proteins, such as chaperones that prevent proteolysis; adaptors for mediating interactions between proteins; regulators of intracellular protein distribution and transcriptional regulators (Davis et al. 2009). This multitude of functions suggests that the 14-3-3 proteins may have a key role in co-ordination of mitosis, metabolism, stress response and organelle trafficking as the feeding site develops.

Although the cell cycle is activated to form the NFS, the nematodes secrete more effector molecules to maintain and regulate GC and syncytium development. The calcium concentration is critical for signalling pathways, molecular chaperone activity in the ER, cell adhesion, defence response, cell death by apoptosis, recovery from wounds and pathogenesis. Calreticulin (CRT) has been isolated from root-knot nematode secretions via a proteomic approach (Jaubert et al. 2002b). The function of CRT in calcium homeostasis and protein maturation is believed to assist in the maintenance of GCs by providing pressure support as well as aiding intercellular trafficking.

A calcium dependent protein kinase (CDPK1) (Ivashuta et al. $2005)$ and several calmodulin $(\mathrm{CaM})$ proteins have been identified in the M. incognita secretome (Bellafiore et al. 2008). This report proposed that secretion of CDPK1 and other $\mathrm{CaM}$ proteins into plant cells may allow the nematodes to take control of a central element of plant signalling pathways. Modulation of these pathways could affect cell expansion, cell wall synthesis and defence responses, all of which could assist the establishment of parasitising nematodes.

Regulation of calcium also has a profound impact on several membrane-associated processes in plants. Recently, effector molecules having similarity to - and possibly mimicking plant annexins were isolated from soybean and beet cyst nematodes (Patel et al. 2010). The authors suggest that the annexins may promote parasitism by aiding the establishment and maintenance of NFS through increasing oxidoreductase activity upon binding with calcium at the membrane surfaces.

Secretory translationally controlled tumour proteins (TCTPs) are expressed within the subventral glands of $M$. incognita (Bellafiore et al. 2008). TCTPs were first reported to have calcium-binding activity; however, additional roles in cell cycle and growth have since been discovered. In humans, 
these molecules contain a tubulin-binding region that binds to the microtubules during most of the cell cycle. The concentration of TCTPs controls the rate of mitosis and this protein is usually found at a higher level in tumour cells (Bommer and Thiele 2004). One hypothesis is that the nematode-secreted TCTPs control the rate of cell divisions during the development of a feeding site. These molecules also have roles in protection from apoptosis and cell stress (Bellafiore et al. 2008).

A nematode surface protein (FAR-1) belonging to the fatty acid and retinol-binding protein family was identified from Globodera pallida (Prior et al. 2001). The ability of FAR-1 to bind precursors of the plant jasmonic acid signalling pathway suggests that it has a role in modulating plant defence responses.

Although bacterial, viral and fungal plant pathogens have long been known to trigger host resistance mechanisms via avirulence proteins, no such proteins were characterised from nematodes. Recently, two exciting studies identified secreted Spal and RYanodine receptor (SPRY) domain proteins (SPRYSEC) from G. pallida (Sacco et al. 2009) and Globodera rostochiensis (Rehman et al. 2009b), which were shown to bind NB-LRR (nucleotide binding and leucine-rich repeat) proteins similar to pathogen resistance proteins. This led to a hypersensitive response in tobacco in the case of the G. pallida effector RBP-1 (Sacco et al. 2009), suggesting that nematode effectors can act as virulence factors regulating host immune responses to nematodes.

\section{Effector proteins that could alter plant gene expression}

The existence of nuclear localisation signals (NLS) in many of the secreted proteins suggests that these proteins move to the plant cell nucleus, where they alter plant gene expression (Gao et al. 2003; Huang et al. 2003; Elling et al. 2007, 2009; Bellafiore et al. 2008). This could be important in re-programming the cell cycle. Progression of the cell cycle is in part driven by the Skp, Cullin, FBox containing complex (SCF), which provides the ubiquitinprotein ligase activity. A homologue of S-phase kinase associated protein (SKP-1) having a NLS has been identified in the secretome of cyst nematodes (Gao et al. 2003). SKP-1 is an integral component of SCF and its secretion by the nematodes, coupled with nuclear localisation, may be involved in inducing multiple S-phases without cytokinesis in the development of the hypertrophied multinucleated cells of the syncytia (Bellafiore et al. 2008).

A class of ubiquitin extension proteins has been identified from cyst nematodes (Gao et al. 2003; Tytgat et al. 2004). These proteins are likely targeted to the nucleolus of the plant host cell, where they could play a role in ribosome synthesis, nuclear transport or cell cycle regulation. As these proteins have not been detected in RKNs, they might have a function in syncytium development (Tytgat et al. 2004).

A putative secreted histone deacetylase was identified from $H$. glycines, which shows similarity to plant histone deacetylases (Elling et al. 2009). Further research could test whether epigenetic mechanisms are involved in altering host gene expression and to determine which host genes are targeted by this mechanism.

In addition, several helicases, RNA and DNA-binding proteins, histones and nucleosome assembly proteins with likely roles in modifying host gene expression have been identified from M. incognita (Bellafiore et al. 2008).

\section{Outlook}

Many questions remain about the functions of nematode effectors and their roles in altering root cell development. The availability of technology for silencing nematode effectors through expression of RNAi silencing constructs in plant hosts is a powerful resource for functional studies of the many candidate effector proteins (Table 1) (Huang et al. 2006a; Rosso et al. 2009). However, there is much more to discover about nematode effectors - the plant proteins that they interact with; the systemic functions that they may have in the whole plant; whether they move from the cells into which they are injected; or whether, and how, several effectors function together. In addition, little is known about potential effectors expressed on the nematode surface (Prior et al. 2001) or secreted by the anterior amphids or the posterior phasmids, and these merit investigation. In addition, future efforts should be directed at characterising effectors and their function in migratory endo- and ectoparasites, many of which await genomic sequencing.

A further aspect of nematode effectors requiring research is their evolutionary origin. Many effectors seem to have been acquired through horizontal gene transfer (Smant et al. 1998; Abad et al. 2008; Bird et al. 2009). Although several cell wall modifying enzymes have been acquired from plants or bacteria by the sedentary endoparasitic nematodes, some of the migratory nematodes appear to have acquired some of their effector genes from fungi, which are additional food sources for many of these parasites (Jones et al. 2005). The use of signal mimics and the targeting of signalling pathways similar to those used in other plant-microbe interactions, for example, nodulation (Bird and Koltai 2000; Weerasinghe et al. 2005), underlines the long coevolution of parasitic nematodes with their hosts and other rhizosphere organisms.

\section{Acknowledgements}

We apologise to authors whose work we could not cite here due to space limitations. Work in our laboratories was funded by the Grains Research and Development Corporation (ANU00006), the Australian Research Council Centre of Excellence for Integrative Legume Research (CE0348212) and an Australian Research Fellowship to UM (DP0557692).

\section{References}

Abad P, Gouzy J, Aury J-M, Castagnone-Sereno P, Danchin EGJ, et al. (2008) Genome sequence of the metazoan plant-parasitic nematode Meloidogyne incognita. Nature Biotechnology 26, 909-915. doi:10.1038/nbt. 1482

Adam MAM, Phillips MS, Jones JT, Blok VC (2008) Characterisation of the cellulose-binding protein Mj-cbp-1 of the root-knot nematode, Meloidogyne javanica. Physiological and Molecular Plant Pathology 72, 21-28. doi:10.1016/j.pmpp.2008.05.002

Bekal S, Niblack TL, Lambert KN (2003) A chorismate mutase from the soybean cyst nematode Heterodera glycines shows polymorphisms that correlate with virulence. Molecular Plant-Microbe Interactions 16, 439-446. doi:10.1094/MPMI.2003.16.5.439

Bellafiore S, Shen ZX, Rosso MN, Abad P, Shih P, Briggs SP (2008) Direct identification of the Meloidogyne incognita secretome reveals proteins with host cell reprogramming potential. PLoS Pathogens 4, e1000192. doi:10.1371/journal.ppat.1000192 
Bird DM, Koltai H (2000) Plant parasitic nematodes: habitats, hormones, and horizontally-acquired genes. Journal of Plant Growth Regulation 19, 183-194.

Bird DM, Opperman CH (2009) The secret(ion) life of worms. Genome Biology 10, 205. doi:10.1186/gb-2009-10-1-205

Bird DM, Williamson VM, Abad P, McCarter J, Danchin EGJ, CastagnoneSereno P, Opperman CH (2009) The genomes of root-knot nematodes. Annual Review of Phytopathology 47, 333-351. doi:10.1146/annurevphyto-080508-081839

Blanchard A, Esquibet M, Fouville D, Grenier E (2005) Ranbpm homologue genes characterised in the cyst nematodes Globodera pallida and Globodera 'mexicana'. Physiological and Molecular Plant Pathology 67, 15-22. doi:10.1016/j.pmpp.2005.09.001

Bommer U-A, Thiele B-J (2004) The translationally controlled tumour protein (TCTP). International Journal of Biochemistry \& Cell Biology 36, 379-385. doi:10.1016/S1357-2725(03)00213-9

Caillaud MC, Dubreuil G, Quentin M, Perfus-Barbeoch L, Lecornte P, Engler JD, Abad P, Rosso MN, Favery B (2008) Root-knot nematodes manipulate plant cell functions during a compatible interaction. Journal of Plant Physiology 165, 104-113. doi:10.1016/j.jplph.2007. 05.007

Chen Q, Rehman S, Smant G, Jones JT (2005) Functional analysis of pathogenicity proteins of the potato cyst nematode Globodera rostochiensis using RNAi. Molecular Plant-Microbe Interactions 18, 621-625. doi:10.1094/MPMI-18-0621

Cock JM, McCormick S (2001) A large family of genes that share homology with CLAVATA3. Plant Physiology 126, 939-942. doi:10.1104/pp.126. 3.939

Davis EL, Hussey RS, Mitchum MG, Baum TJ (2008) Parasitism proteins in nematode-plant interactions. Current Opinion in Plant Biology 11, 360-366. doi:10.1016/j.pbi.2008.04.003

Davis E, Hussey R, Baum T (2009) Parasitism genes: what they reveal about parasitism. In 'Cell biology of plant nematode parasitism'. (Eds RG Berg, CJ Taylor) pp. 15-44. (Springer-Verlag: Berlin)

de Boer JM, Yan YT, Wang XH, Smant G, Hussey RS, Davis EL, Baum TJ (1999) Developmental expression of secretory beta-1,4-endoglucanases in the subventral esophageal glands of Heterodera glycines. Molecular Plant-Microbe Interactions 12, 663-669. doi:10.1094/MPMI.1999.12. 8.663

de Boer JM, McDermott JP, Davis EL, Hussey RS, Popeijus H, Smant G, Baum TJ (2002) Cloning of a putative pectate lyase gene expressed in the subventral esophageal glands of Heterodera glycines. Journal of Nematology 34, 9-11.

de Meutter J, Tytgat T, Witters E, Gheysen G, van Onckelen H, Gheysen G (2003) Identification of cytokinins produced by the plant parasitic nematodes Heterodera schachtii and Meloidogyne incognita. Molecular Plant Pathology 4, 271-277. doi:10.1046/j.1364-3703.2003. 00176.x

de Meutter J, Tytgat T, Prinsen E, Gheysen G, van Onckelen H (2005) Production of auxin related compounds by the plant parasitic nematodes Heterodera schachtii and Meloidogyne incognita. Communications in Agricultural and Applied Biological Sciences 70, 51-60.

Decraemer W, Hunt DJ (2006) Structure and classification. In 'Plant nematology'. (Eds RN Perry, M Moens) pp. 3-33. (CABI International: Wallingford)

Ding X, Shields J, Allen R, Hussey RS (1998) A secretory cellulose-binding protein cDNA cloned from the root-knot nematode (Meloidogyne incognita). Molecular Plant-Microbe Interactions 11, 952-959. doi:10.1094/MPMI.1998.11.10.952

Ding X, Shields J, Allen R, Hussey RS (2000) Molecular cloning and characterisation of a venom allergen AG5-like cDNA from Meloidogyne incognita. International Journal for Parasitology 30, 77-81. doi:10.1016/S0020-7519(99)00165-4
Doyle EA, Lambert KN (2002) Cloning and characterization of an esophageal-gland-specific pectate lyase from the root-knot nematode Meloidogyne javanica. Molecular Plant-Microbe Interactions $\mathbf{1 5}$, 549-556. doi:10.1094/MPMI.2002.15.6.549

Doyle EA, Lambert KN (2003) Meloidogyne javanica chorismate mutase 1 alters plant cell development. Molecular Plant-Microbe Interactions 16, 123-131. doi:10.1094/MPMI.2003.16.2.123

Elling AA, Davis EL, Hussey RS, Baum TJ (2007) Active uptake of cyst nematode parasitism proteins into the plant cell nucleus. International Journal for Parasitology 37, 1269-1279. doi:10.1016/j.ijpara.2007. 03.012

Elling AA, Mitreva M, Gai XW, Martin J, Recknor J, Davis EL, Hussey RS, Nettleton D, McCarter JP, Baum TJ (2009) Sequence mining and transcript profiling to explore cyst nematode parasitism. BMC Genomics 10, 58. doi:10.1186/1471-2164-10-58

Estelle M (2001) Proteases and cellular regulation in plants. Current Opinion in Plant Biology 4, 254-260. doi:10.1016/S1369-5266(00) 00169-2

Fiers M, Ku KL, Liu CM (2007) CLE peptide ligands and their roles in establishing meristems. Current Opinion in Plant Biology 10, 39-43. doi:10.1016/j.pbi.2006.11.003

Gao B, Allen R, Maier T, Davis EL, Baum TJ, Hussey RS (2001a) Identification of putative parasitism genes expressed in the esophageal gland cells of the soybean cyst nematode Heterodera glycines. Molecular Plant-Microbe Interactions 14, 1247-1254. doi:10.1094/MPMI.2001. 14.10.1247

Gao B, Allen R, Maier T, Davis EL, Baum TJ, Hussey RS (2001b) Molecular characterisation and expression of two venom allergen-like protein genes in Heterodera glycines. International Journal for Parasitology 31, 1617-1625. doi:10.1016/S0020-7519(01)00300-9

Gao B, Allen R, Maier T, Davis EL, Baum TJ, Hussey RS (2003) The parasitome of the phytonematode Heterodera glycines. Molecular Plant-Microbe Interactions 16, 720-726. doi:10.1094/MPMI.2003. 16.8 .720

Gao B, Allen R, Davis EL, Baum TJ, Hussey RS (2004) Molecular characterisation and developmental expression of a cellulose-binding protein gene in the soybean cyst nematode Heterodera glycines. International Journal for Parasitology 34, 1377-1383. doi:10.1016/j. ijpara.2004.09.001

Geldhof P, Vercauteren I, Knox D, Demaere V, Van Zeveren A, Berx G, Vercruysse J, Claerebout E (2003) Protein disulphide isomerase of Ostertagia ostertagi: an excretory-secretory product of L4 and adult worms? International Journal for Parasitology 33, 129-136. doi:10.1016/S0020-7519(02)00260-6

Gheysen G, Fenoll C (2002) Gene expression in nematode feeding sites. Annual Review of Phytopathology 40, 191-219. doi:10.1146/annurev. phyto.40.121201.093719

Goellner M, Smant G, De Boer JM, Baum TJ, Davis EL (2000) Isolation of beta-1,4-endoglucanase genes from Globodera tabacum and their expression during parasitism. Journal of Nematology 32, $154-165$.

Goellner M, Wang XH, Davis EL (2001) Endo-beta-1,4-glucanase expression in compatible plant-nematode interactions. The Plant Cell 13, 2241-2255.

Goverse A, van der Voort JR, van der Voort CR, Kavelaars A, Smant G, Schots A, Bakker J, Helder J (1999) Naturally induced secretions of the potato cyst nematode co-stimulate the proliferation of both tobacco leaf protoplasts and human peripheral blood mononuclear cells. Molecular Plant-Microbe Interactions 12, 872-881. doi:10.1094/MPMI.1999.12. 10.872

Goverse A, Engler JD, Verhees J, van der Krol S, Helder J, Gheysen G (2000) Cell cycle activation by plant parasitic nematodes. Plant Molecular Biology 43, 747-761. doi:10.1023/A:1006367126077 
Grunewald W, Cannoot B, Friml J, Gheysen G (2009a) Parasitic nematodes modulate PIN-mediated auxin transport to facilitate infection. PLoS Pathogens 5, e1000266. doi:10.1371/journal.ppat.10 00266

Grunewald W, van Noorden G, van Isterdael G, Beeckman T, Gheysen G, Mathesius U (2009b) Manipulation of auxin transport in plant roots during Rhizobium symbiosis and nematode parasitism. The Plant Cell 21, 2553-2562. doi:10.1105/tpc.109.069617

Haegeman A, Jacob J, Vanholme B, Kyndt T, Mitreva M, Gheysen G (2009a) Expressed sequence tags of the peanut pod nematode Ditylenchus africanus: the first transcriptome analysis of an Anguinid nematode. Molecular and Biochemical Parasitology 167, 32-40. doi:10.1016/j. molbiopara.2009.04.004

Haegeman A, Vanholme B, Gheysen G (2009b) Characterization of a putative endoxylanase in the migratory plant-parasitic nematode Radopholus similis. Molecular Plant Pathology 10, 389-401. doi:10.1111/j.13643703.2009.00539.x

Hewezi T, Howe P, Maier TR, Hussey RS, Mitchum MG, Davis EL, Baum TJ (2008) Cellulose binding protein from the parasitic nematode Heterodera schachtii interacts with Arabidopsis pectin methylesterase: co-operative cell wall modification during parasitism. The Plant Cell 20, 3080-3093. doi:10.1105/tpc. 108.063065

Hewezi T, Howe PJ, Maier TR, Hussey RS, Mitchum MG, Davis EL, Baum TJ (2010) Arabidopsis spermidine synthase is targeted by an effector protein of the cyst nematode Heterodera schachtii. Plant Physiology 152, 968-984. doi:10.1104/pp.109.150557

Hogenhout SA, van der Hoorn RAL, Terauchi R, Kamoun S (2009) Emerging concept in effector biology of plant-associated organisms. Molecular Plant-Microbe Interactions 22, 115-122. doi:10.1094/ MPMI-22-2-0115

Huang G, Gao B, Maier T, Allen R, Davis EL, Baum TJ, Hussey RS (2003) A profile of putative parasitism genes expressed in the esophageal gland cells of the root-knot nematode Meloidogyne incognita. Molecular Plant-Microbe Interactions 16, 376-381. doi:10.1094/MPMI. 2003.16.5.376

Huang GZ, Dong RH, Maier T, Allen R, Davis EL, Baum TJ, Hussey RS (2004) Use of solid-phase subtractive hybridization for the identification of parasitism gene candidates from the root-knot nematode Meloidogyne incognita. Molecular Plant Pathology 5, 217-222. doi:10.1111/j.13643703.2004.00220.x

Huang G, Dong R, Allen R, Davis EL, Baum TJ, Hussey RS (2005) Developmental expression and molecular analysis of two Meloidogyne incognita pectate lyase genes. International Journal for Parasitology $\mathbf{3 5}$, 685-692. doi:10.1016/j.ijpara.2005.01.006

Huang G, Allen R, Davis EL, Baum TJ, Hussey R (2006a) Engineering broad root-knot resistance in transgenic plants by RNAi silencing of a conserved and essential root-knot nematode parasitism gene. Proceedings of the National Academy of Sciences of the United States of America 103, 14302-14306. doi:10.1073/pnas.0604698103

Huang G, Dong R, Allen R, Davis EL, Baum TJ, Richard SH (2006b) A rootknot nematode secretory peptide functions as a ligand for a plant transcription factor. Molecular Plant-Microbe Interactions 19, 463-470. doi:10.1094/MPMI-19-0463

Hutangura P, Mathesius U, Jones MGK, Rolfe BG (1999) Auxin induction is a trigger for root-gall formation caused by root-knot nematodes in white clover and is associated with the activation of the flavonoid pathway. Australian Journal of Plant Physiology 26, 221-231. doi:10.1071/ PP98157

Ithal N, Recknor J, Nettleton D, Hearne L, Maier T, Baum TJ, Mitchum MG (2007) Parallel genome-wide expression profiling of host and pathogen during soybean cyst nematode infection of soybean. Molecular Plant-Microbe Interactions 20, 293-305. doi:10.1094/ MPMI-20-3-0293
Ivashuta S, Liu J, Liu J, Lohar DP, Haridas S, Bucciarelli B, VandenBosch KA, Vance CP, Harrison MJ, Gantt JS (2005) RNA interference identifies a calcium-dependent protein kinase involved in Medicago truncatula root development. The Plant Cell 17, 2911-2921. doi:10.1105/tpc. 105.035394

Jaubert S, Laffaire J-B, Abad P, Rosso M-N (2002a) A polygalacturonase of animal origin isolated from the root-knot nematode Meloidogyne incognita. FEBS Letters 522, 109-112. doi:10.1016/S0014-5793(02) 02906-X

Jaubert S, Ledger TN, Laffaire JB, Piotte C, Abad P, Rosso MN (2002b) Direct identification of stylet secreted proteins from root-knot nematodes by a proteomic approach. Molecular and Biochemical Parasitology 121, 205-211. doi:10.1016/S0166-6851(02)00034-8

Jaubert S, Laffaire JB, Ledger TN, Escoubas P, Amri EZ, Abad P, Rosso MN (2004) Comparative analysis of two 14-3-3 homologues and their expression pattern in the root-knot nematode Meloidogyne incognita. International Journal for Parasitology 34, 873-880. doi:10.1016/j. ijpara.2004.02.008

Jaubert S, Milac AL, Petrescu AJ, de Almelda-Engler J, Abad P, Rosso MN (2005) In planta secretion of a calreticulin by migratory and sedentary stages of root-knot nematode. Molecular Plant-Microbe Interactions 18, 1277-1284. doi:10.1094/MPMI-18-1277

Jones MGK (1981) Host cell responses to endoparasitic nematode attack: structure and function of giant cells and syncytia. The Annals of Applied Biology 97, 353-372. doi:10.1111/j.1744-7348.1981.tb05122.x

Jones JT, Furlanetto C, Kikuchi T (2005) Horizontal gene transfer from bacteria and fungi as a driving force in the evolution of plant parasitism in nematodes. Nematology 7, 641-646. doi:10.1163/ 156854105775142919

Jones JT, Kumar A, Pylypenko LA, Thirugnanasambandum A, Castelli L, et al. (2009) Identification and functional characterization of effectors in expressed sequence tags from various life cycle stages of the potato cyst nematode Globodera pallida. Molecular Plant Pathology 10, 815-828. doi:10.1111/j.1364-3703.2009.00585.x

Kang JS, Lee H, Moon IS, Lee Y, Koh YH, Je YH, Lim KJ, Lee SH (2009) Construction and characterization of subtractive stage-specific expressed sequence tag (EST) libraries of the pinewood nematode Bursaphelenchus xylophilus. Genomics 94, 70-77. doi:10.1016/ j.ygeno.2009.03.001

Karczmarek A, Overmars H, Helder J, Goverse A (2004) Feeding cell development by cyst and root-knot nematodes involves a similar early, local and transient activation of a specific auxin-inducible promoter element. Molecular Plant Pathology 5, 343-346. doi:10.1111/j.13643703.2004.00230.x

Kikuchi T, Jones JT, Aikawa T, Kosaka H, Ogura N (2004) A family of glycosyl hydrolase family 45 cellulases from the pine wood nematode Bursaphelenchus xylophilus. FEBS Letters 572, 201-205. doi:10.1016/j. febslet.2004.07.039

Kikuchi T, Shibuya H, Jones JT (2005) Molecular and biochemical characterization of an endo-beta-1,3-glucanase from the pinewood nematode Bursaphelenchus xylophilus acquired by horizontal gene transfer from bacteria. The Biochemical Journal 389, 117-125. doi:10.1042/BJ20042042

Kikuchi T, Shibuya H, Aikawa T, Jones JT (2006) Cloning and characterization of pectate lyases expressed in the esophageal gland of the pine wood nematode Bursaphelenchus xylophilus. Molecular Plant-Microbe Interactions 19, 280-287. doi:10.1094/ MPMI-19-0280

Kikuchi T, Li HM, Karim N, Kennedy MW, Moens M, Jones JT (2009) Identification of putative expansin-like genes from the pine wood nematode, Bursaphelenchus xylophilus, and evolution of the expansin gene family within the Nematoda. Nematology 11,355-364. doi:10.1163/ 156854109 X446953 
Kudla U, Qin L, Milac A, Kielak A, Maissen C, et al. (2005) Origin, distribution and 3D-modeling of Gr-EXPB1, an expansin from the potato cyst nematode Globodera rostochiensis. FEBS Letters 579, 2451-2457. doi:10.1016/j.febslet.2005.03.047

Ledger TN, Jaubert S, Bosselut N, Abad P, Rosso MN (2006) Characterization of a new beta-1,4-endoglucanase gene from the root-knot nematode Meloidogyne incognita and evolutionary scheme for phytonematode family 5 glycosyl hydrolases. Gene 382, 121-128. doi:10.1016/j. gene.2006.06.023

Lilley CJ, Urwin PE, Atkinson HJ (1999) Characterization of plant nematode genes: identifying targets for a transgenic defence. Parasitology 118, 63-72. doi:10.1017/S0031182099004059

Lu SW, Chen SY, Wang JY, Yu H, Chronis D, Mitchum MG, Wang XH (2009) Structural and functional diversity of CLAVATA3/ESR (CLE)like genes from the potato cyst nematode Globodera rostochiensis. Molecular Plant-Microbe Interactions 22, 1128-1142. doi:10.1094/ MPMI-22-9-1128

Mitchum MG, Wang X, Davis EL (2008) Diverse and conserved roles of CLE peptides. Current Opinion in Plant Biology 11, 75-81. doi:10.1016/ j.pbi.2007.10.010

Mitreva-Dautova M, Roze E, Overmars H, de Graaff L, Schots A, Helder J, Goverse A, Bakker J, Smant G (2006) A symbiont-independent endo-1,4$\beta$-xylanase from the plant-parasitic nematode Meloidogyne incognita. Molecular Plant-Microbe Interactions 19, 521-529. doi:10.1094/MPMI19-0521

Oelkers K, Goffard N, Weiller G, Gresshoff P, Mathesius U, Frickey T (2008) Bioinformatic analysis of the CLE signaling peptide family. BMC Plant Biology 8, 1. doi:10.1186/1471-2229-8-1

Olsen AN, Skriver K (2003) Ligand mimicry? Plant-parasitic nematode polypeptide with similarity to CLAVATA3. Trends in Plant Science $\mathbf{8}$, 55-57. doi:10.1016/S1360-1385(03)00003-7

Patel N, Hamamouch N, Li CY, Hewezi T, Hussey RS, Baum TJ, Mitchum MG, Davis EL (2010) A nematode effector protein similar to annexins in host plants. Journal of Experimental Botany 61, 235-248. doi:10.1093/ jxb/erp293

Popeijus H, Overmars H, Jones J, Blok V, Goverse A, Helder J, Schots A, Bakker J, Smant G (2000) Enzymology: degradation of plant cell walls by a nematode. Nature 406, 36-37. doi:10.1038/35017641

Prior A, Jones JT, Blok VC, Beauchamp J, McDermott L, Cooper A, Kennedy MW (2001) A surface-associated retinol- and fatty acidbinding protein (Gp-FAR-1) from the potato cyst nematode Globodera pallida: lipid binding activities, structural analysis and expression pattern. The Biochemical Journal 356, 387-394. doi:10.1042/02646021:3560387

Qin L, Overmars H, Helder J, Popeijus H, van der Voort JR, Groenink W, van Koert P, Schots A, Bakker J, Smant G (2000) An efficient cDNAAFLP-based strategy for the identification of putative pathogenicity factors from the potato cyst nematode Globodera rostochiensis. Molecular Plant-Microbe Interactions 13, 830-836. doi:10.1094/ MPMI.2000.13.8.830

Qin L, Kudla U, Roze EHA, Goverse A, Popeijus H, et al. (2004) Plant degradation: a nematode expansin acting on plants. Nature 427, 30. doi:10.1038/427030a

Rehman S, Butterbach P, Popeijus H, Overmars H, Eric LD, Jones JT, Goverse A, Bakker J, Smant G (2009a) Identification and characterization of the most abundant cellulase in stylet secretions from Globodera rostochiensis. Phytopathology 99, 194-202. doi:10.1094/PHYTO-992-0194

Rehman S, Postma W, Tytgat T, Prins P, Qin L, et al. (2009b) A secreted SPRY domain-containing protein (SPRYSEC) from the plant-parasitic nematode Globodera rostochiensis interacts with a CC-NB-LRR protein from a susceptible tomato. Molecular Plant-Microbe Interactions 22, 330-340. doi:10.1094/MPMI-22-3-0330
Rosso MN, Favery B, Piotte C, Arthaud L, De Boer JM, Hussey RS, Bakker J, Baum TJ, Abad P (1999) Isolation of a cDNA encoding a beta-1,4-endoglucanase in the root-knot nematode Meloidogyne incognita and expression analysis during plant parasitism. Molecular Plant-Microbe Interactions 12, 585-591. doi:10.1094/ MPMI.1999.12.7.585

Rosso MN, Jones JT, Abad P (2009) RNAi and functional genomics in plant parasitic nematodes. Annual Review of Phytopathology 47, 207-232. doi:10.1146/annurev.phyto.112408.132605

Roze E, Hanse B, Mitreva M, Vanholme B, Bakker J, Smant G (2008) Mining the secretome of the root-knot nematode Meloidogyne chitwoodi for candidate parasitism genes. Molecular Plant Pathology 9, 1-10.

Sacco MA, Koropacka K, Grenier E, Jaubert MJ, Blanchard A, Goverse A, Smant G, Moffett P (2009) The cyst nematode SPRYSEC protein RBP-1 elicits Gpa2- and RanGAP2-dependent plant cell death. PLoS Pathogens 5, e1000564. doi:10.1371/journal.ppat.1000564

Shingles J, Lilley CJ, Atkinson HJ, Urwin PE (2007) Meloidogyne incognita: molecular and biochemical characterisation of a cathepsin $\mathrm{L}$ cysteine proteinase and the effect on parasitism following RNAi. Experimental Parasitology 115, 114-120. doi:10.1016/j.exppara. 2006.07.008

Sindhu AS, Maier TR, Mitchum MG, Hussey RS, Davis EL, Baum TJ (2009) Effective and specific in planta RNAi in cyst nematodes: expression interference of four parasitism genes reduces parasitic success. Journal of Experimental Botany 60, 315-324. doi:10.1093/ jxb/ern289

Smant G, Stokkermans JPWG, Yan Y, de Boer JM, Baum TJ, et al. (1998) Endogenous cellulases in animals: isolation of $\beta$-1,4-endoglucanase genes from two species of plant-parasitic cyst nematodes. Proceedings of the National Academy of Sciences of the United States of America 95, 4906-4911. doi:10.1073/pnas.95.9.4906

Tytgat T, Vanholme B, De Meutter J, Claeys M, Couvreur M, et al. (2004) A new class of ubiquitin extension proteins secreted by the dorsal pharyngeal gland in plant parasitic cyst nematodes. Molecular PlantMicrobe Interactions 17, 846-852. doi:10.1094/MPMI.2004.17.8.846

Uehara T, Kushida A, Momota Y (2001) PCR-based cloning of two beta-1,4endoglucanases from the root-lesion nematode Pratylenchus penetrans. Nematology 3, 335-341. doi:10.1163/156854101317020259

Vanholme B, De Meutter J, Tytgat T, Van Montagu M, Coomans A, Gheysen G (2004) Secretions of plant-parasitic nematodes: a molecular update. Gene 332, 13-27. doi:10.1016/j.gene.2004.02.024

Vanholme B, Mitreva M, Van Criekinge W, Logghe M, Bird D, McCarter J, Gheysen G (2006) Detection of putative secreted proteins in the plantparasitic nematode Heterodera schachtii. Parasitology Research 98, 414-424. doi:10.1007/s00436-005-0029-3

Vanholme B, Haegeman A, Jacob J, Cannoot B, Gheysen G (2009) Arabinogalactan endo-1,4- $\beta$-galactosidase: a putative plant cell walldegrading enzyme of plant-parasitic nematodes. Nematology 11, 739-747. doi:10.1163/156854109X404599

Wang XH, Meyers D, Yan YT, Baum T, Smant G, Hussey R, Davis E (1999) In planta localization of a beta-1,4-endoglucanase secreted by Heterodera glycines. Molecular Plant-Microbe Interactions 12, 64-67. doi:10.1094/ MPMI.1999.12.1.64

Wang X, Allen R, Ding X, Goellner M, Maier T, de Boer JM, Baum TJ, Hussey RS, Davis EL (2001) Signal peptide-selection of cDNA cloned directly from the esophageal gland cells of the soybean cyst nematode Heterodera glycines. Molecular Plant-Microbe Interactions 14, 536-544. doi:10.1094/MPMI.2001.14.4.536

Wang X, Mitchum MG, Gao B, Li C, Diab H, Baum TJ, Hussey RS, Davis EL (2005) A parasitism gene from a plant-parasitic nematode with function similar to CLAVATA3/ESR (CLE) of Arabidopsis thaliana. Molecular Plant Pathology 6, 187-191. doi:10.1111/j.1364-3703.2005.00270.x 
Wang X, Li H, Hu Y, Fu P, Xu J (2007) Molecular cloning and analysis of a new venom allergen-like protein gene from the root-knot nematode Meloidogyne incognita. Experimental Parasitology 117, 133-140. doi:10.1016/j.exppara.2007.03.017

Wang J, Lee C, Replogle A, Joshi S, Korkin D, Hussey RS, Baum TJ, Davis EL, Wang X, Mitchum MG (2010) Dual roles for the variable domain in protein trafficking and host-specific recognition of Heterodera glycines CLE effector proteins. New Phytologist 187, 1003-1017. doi:10.1111/ j.1469-8137.2010.03300.x
Weerasinghe RR, Bird DM, Allen NS (2005) Root-knot nematodes and bacterial Nod factors elicit common signal transduction events in Lotus japonicus. Proceedings of the National Academy of Sciences of the United States of America 102, 3147-3152. doi:10.1073/pnas.0407926102

Manuscript received 13 May 2010, accepted 19 July 2010 